at convincing the practical man in Africa is carried out in a masterly way and with full authority in Mr. Smith's Presidential Address, and it is to be hoped that it will be read by a much wider circle than the subscribers to the Anthropological Journal.

After an historical retrospect Mr. Smith deals with subjects such as: What the practical man demands, Progress in the recognition of anthropology, Anthropology and administration, Indirect rule, Anthropology and Christian missions, Some objections to anthropology, The alleged remoteness of anthropology, Anthropology not an enemy to progress.

\title{
New Education Fellowship Conference, Johannesburg (1934), African Section.
}

A special Section of the New Education Fellowship Conference at Johannesburg was devoted to the study of problems of African education; from July I 6 th to $27^{\text {th }}$ the Section met for four hours each morning and for about an hour and a half in the afternoons. Mr. J. D. Rheinallt Jones was chairman. About fifty addresses or papers were given, but in accordance with a programme which, imaginatively conceived, produced from many subjects and many points of view a more than logical unity; speakers were candid in their differences; the chairman's tact was none the less successful for avoiding meaningless formulae.

Professor Malinowski in his address to the first meeting - a symposium on African Indigenous Life-made a number of points which speakers at later meetings, witnessing independently from local experience, only drove farther home. The European by settling in Africa had deprived the Native of his birthright; affected archaisms in education found no support from anthropology; at the same time a merely European education of Natives was impossible; the only solution lay in the return to the Native of full status; our first duty was the education of our own race on the subject. Mrs. Hoernle showed that certain essential native institutions were valuable and happily obstinate even where change of conditions is most striking. Professor Hoernlé, concluding the symposium, declared that psychology proves no difference of kind and only doubtfully a difference in degree between the minds of White and Black; only in their cultures were there real differences which must be respected and considered according to the degree of disintegration which had taken place in various sections of the population; but Bantu culture must learn from the West the scientific attitude. A series of papers followed on the effect of European contact on Bantu belief in magic, on social and economic changes, and on health and diet changes in typical situations. The possibilities of education as an integrating agency were considered next. Professor Malinowski pointed out the importance of supplementing the discipline of the Native in his own community life with schooling 
that would help him to deal with European contacts. Professor Victor Murray, strongly supported by Mr. Jowitt, urged that 'the only thing that can integrate society is a common faith, not a common institution', and that ultimately the only possible integrating factor for African society was the doctrine and example of Christianity; he also made a plea for such higher education as would ' make possible the emergence of 'leaders, and for enlisting the co-operation of Africans. The soundness of this plea was amply shown in the actual contributions to the discussions by the African chiefs and teachers who were present.

The discourse on tests of educability threw perhaps a little light on the applicability of those tests to purposes for which they were never intended, but none on the subject in hand. And the discussion on differential treatment was mainly concerned with questions of finance rather than of curriculum: at the same time there was a plea for codes allowing freedom and appropriateness of development according to real conditions and individual genius. In a series of papers on the medium of education the value and necessity of the vernaculars was stressed; the claims of European languages were also excellently stated by the Rev. 'T. K. Motsete. Next came problems relating to the content of education, special attention being paid to rural education, the education of girls, and religious education. In all of these the co-operation of Africans and the training of Africans by co-operation for full responsibility was shown to be essential. Papers on occupational training emphasized the educational value of a reasonable prospect of profitable employment; and Professor Clarke, concluding this discussion, urged that the raising of the Natives' standard of life would be in the interests of the country as a whole. The relations of educational administrations with missions were then discussed, and finally teacher-training and Jeanes teacher-training. It was recognized that such training is the key to almost the whole situation.

A special joint meeting of anthropologists, educationists, and missionaries drew up a statement defining the roles of each in assisting the development of the African, and the essentials of such development. The chairman summed up the findings of the Section at the final general meeting of the Conference.

A feature of the meetings of the Section was the publicinterest they aroused -or, more correctly, discovered-in the Union of South Africa. A full report, separate from the report of the rest of the Conference, is to be published. (Communicated by Mr. G. H. Wruson, Superintendent of Education in Northern Rhodesia.)

\section{A New Orthography for Xhosa.}

The orthography recommended by the Xhosa Sub-Committee on Orthography appointed in 1929 under the Advisory Committee on Bantu Studies 